\title{
Some Thoughts on the Structure of Bamboo Leaves
}

\author{
by C. R. Metcalfe*
}

Received June 18, 1956

\section{Introduction}

In the course of a general survey of the comparative anatomy of the vegetative organs of the Monocotyledons, which is now in progress at the Jodrell Laboratory, at Kew, I have devoted considerable attention to the Gramineae. It is becoming increasingly recognized by students of grass taxonomy that certain microscopical characters visible in the leaf epidermis, and in transverse sections through the lamina, are of considerable importance in the basic classification of the Gramineae. Other microscopical characters of the vegetative organs are also valuable if used judiciously, for identifying species when the genus has already been established by traditional macroscopical characters. This has been fully confirmed by the work at Kew, and indeed, taking a broad view of the Gramineae, it can be seen that there is an anatomical pattern which roughly corresponds to some of the major groups into which the grasses are divided for purposes of classification.

Although much attention has now been devoted by various authors, to a wide range of grasses, it is a notable fact that comparatively little attention has been devoted to the bamboos, although some very useful contributions have been made. Thus we have the detailed work of Ohki $(3,4)$ on the spodograms of the leaves of the Bambusaceae, in which the epidermal characters of a number of species of some 10 genera have been described. At a much earlier date there was the work by Brandis (1), whose paper has become a classic, and, more recently Prat (6) has referred to the structure of bamboo leaves as part of his well known contribution to the anatomy of the epidermis of grass leaves. Page (5) has reviewed the leaf structure of Streptochaeta in relation to that of the bamboos, and certain African bomboos have only recently received attention from Jacques-Félix (2). These selected references by no means exhaust the bibliography, but they will serve as a background for the present discussion.

\section{Transverse section of the lamina}

(i) Structure of the mesophyll.

It is familiar to most students of grass anatomy that the structure of the as-

* Jodrell Laboratory, Royal Botanic Gardens, Kew, Great Britain 

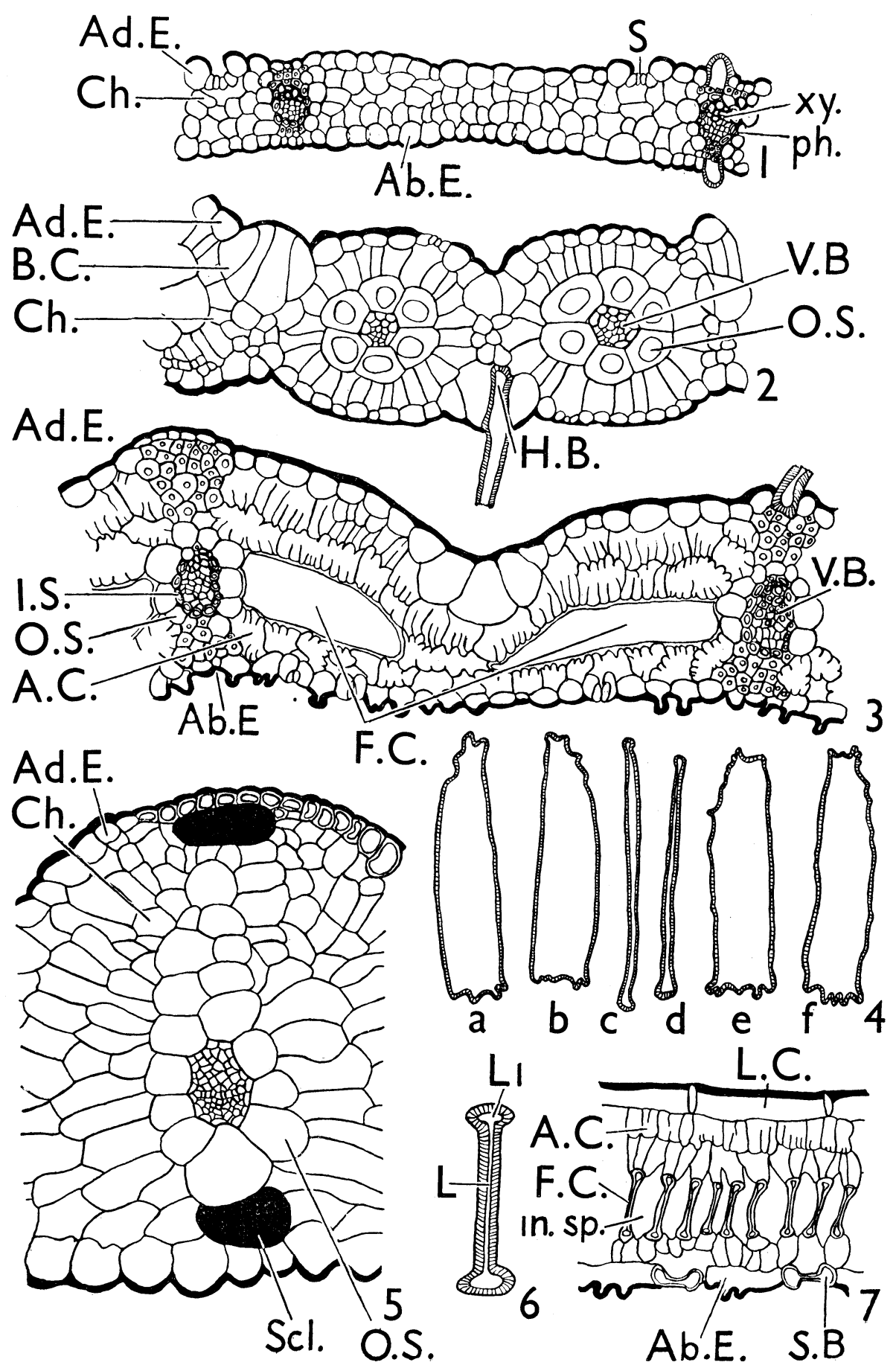

Ab.E. S.B 
similatory tissue in the mesophyll of most panicoid grasses is radiate, in the sense that the cells of which it is composed are arranged in a radial manner around each of the vascular bundles. In the festucoid grasses no indication of the radiate arrangement of the mesophyll around the vascular bundles is to be seen. As more and more grasses are examined, however, it is found that there is no clear cut line of demarcation between these 2 types of mesophyll in grass leaves, since there are some in which a vague, or incompletely radiate arrangement of the mesophyll is to be seen. Furthermore one can distinguish grasses with relatively short assimilatory cells arranged in a very conspicuously radiate manner, e. g. Panicum capillare Linn. (Fig. I, 2) from those in which the radiating cells are long, narrow, and often form a somewhat spongy part of the mesophyll. This type of structure (Fig. I, 5) has been noted particularly in certain species of Isachne and allied genera, and it may for convenience be termed the Isachne type of mesophyll. Melica uniflora Retz. (Fig. I, 1) affords a good example of a grass with the non-radiate type of mesophyll. For our present purpose it should be noted that the Bambuseae, so far as I am aware without exception, exhibit the non-radiate arrangement of the mesophyll.

Fig. I. 1. Melica uniflora. T.S. lamina with festucoid mesophyll, the chlorenchyma (Ch.) not being arranged radiately around the vascular bundles. $\times 220$.

2. Panicum capillare. T. S. lamina with panicoid mesophyll, the chlorenchyma being arranged radiately around the vascular bundles. $\times 220$.

3. Arundinaria auricoma. T. S. lamina showing the type of mesophyll characteristic of bamboos, with chlorenchyma composed of arm-cells (A. C.) and translucent fusoid cells (F.C.) $\times 220$.

4. Dinochloa m'clellandii. a, b, e \& $\mathrm{f}$ fusoid cells from a macerated leaf lying on their sides, i.e. more or less as they appear in transverse sections of the leaf at right angles to its long axis. c \& d fusoid cells, from a macerated leaf, standing on their edges, i. e. as they would appear in a paradermal section. $\times 220$.

5. Isachne kunthiana. T. S. of a small portion of the lamina passing through a vascular bundle, showing the chlorenchyma arranged in a more or less radiating manner around the vascular bundle. The assimilatory cells are often narrower and more elongated than those shown in the figure. This type of mesophyll, which is very spongy, and of which it is difficult to prepare sections, is highly characteristic of Isachne and allied genera. $\times 300$.

6. Arundinaria auricoma. Reconstruction of a fusoid cell as seen in a T.S. of the lamina parallel to the long axis of the leaf. These cells always appear to have contracted, so that the narrow lumen $\mathrm{L}$ is often invisible or is seen as a single line. The wider portion of the lumen at either end of the cell $\left(L_{1}\right)$ can sometimes be seen more clearly. The collapsed condition of the fusoid cells has led to difficulty in interpreting their structure.

7. Arundinaria auricoma. Lamina parallel to the long axis of the leaf, showing long cells (L.C.) alternating with short cells, of the adaxial epidermis; chlorenchyma composed of arm-cells (A.C.); a single row of fusoid cells (F.C.), separated from one another by intercellular spaces (in. sp.). Two dumb-bell shaped silica bodies (S.B.) are to be seen in the abaxial epidermis (Ab.E.). $\times 220$.

Ab.E., abaxial epidermis. A.C., arm-cells. Ad.E., adaxial epidermis, B.C., bulliform cells. Ch. chlorenchyma. F.C., fusoid cells. H.B., base of hair. I.S., inner bundle sheath. in. sp., intercellular space. $\mathrm{L}$, lumen of cell. $\mathrm{L}_{1}$, wide lumen at end of cell. O.S. outer bundle sheath. ph, phloem. S., stoma. S.B., silica body. Scl., sclerenchyma. Xy., xylem. 
Another important character in the mesophyll of grasses is that the assimilatory cells are sometimes provided with thin invaginations of the cell walls extending to different depths in the lumina of the cells. Cells of this type can be conveniently referred to as arm-cells. This character is of considerable diagnostic value because of its restricted occurrence amongst the grasses as a whole, but it is noteworthy that arm-cells are especially characteristic of the Oryzeae and Bambuseae. The arm-cells of Arundinaria auricoma are to be seen in Fig. I, 3, A. C. There is, however, one important respect in which the leaves of most bamboos stand out in marked contrast to those of most grasses. I refer to the occurrence of conspicuous, translucent cells in the mesophyll, where they usually have a somewhat fusiform outline when observed in transverse sections of the lamina (Fig. J, 3, F.C.). Brandis (1) recognized that these structures are cells, and not intercellular spaces as had been maintained by certain investigators before his time, although even Brandis himself referred to them as "apparent cavities". Since these cells are usually examined in transverse sections of the lamina, where they are approximately fusiform in outline, they may be referred to for descriptive purposes as fusoid cells. It must be emphasized, however, that the fusoid appearance of the cells is misleading, for they have the form of narrow plates that appear to be fusoid only when they are viewed from one side, either in macerated material (Fig. I, 4, a,b,e,f,) or in transverse sections (Fig. I, 3, A.C.) of the lamina, the long axes of the cells lying at right angles to the long axis of the lamina itself. The lumina of these plate-like cells (Fig. I, 6, L) are very narrow, and it is often very difficult to see them in sections of the leaf parallel with its long axis. Indeed the cells are so thin that they could at first sight be mistaken for cell walls. At the ends of the cells that respectively lie nearest to the adaxial and abaxial surfaces of the leaf, the lumina are slightly wider and more clearly visible (Fig. I, 6, L1 \& 7, F.C.). The appearance of the cells in paradermal sections of the leaf is shown in Fig. I, 4, c-d. Sections parallel to the long axis of the leaf reveal that there are intercellular spaces (Fig. I, 7, in. sp.) between adjacent fusoid cells. Although their development has not been followed in detail, it seems reasonable to suppose that, when first formed, the fusoid cells are in contact with one another, and that they become separated from one another and assume their characteristic and unusual shape during the ontogeny of the leaf. These facts show conclusively that Brandis (1) was correct when he interpreted the translucent areas that are visible in transverse sections of the lamina as cells rather than cavities, and in this he has been followed much more recently by Page (5). It should, however, be noted that Jacques-Félix (2), writing much more recently than Page, refers to the cells as if they were cavities. Fusoid cells are especially characteristic of the mesophyll of bamboos as distinct from other grasses, although they vary considerably in size in different species and genera. In some bamboos, especially in Phyllostachys, they occur sporadically, or are apparently absent. None were to be seen in material of Phyllostachys castillonis, $P$. heterocycla, and $P$. nigra 
grown at Kew, although they were found sporadically in $P$. bambusoides, $P$. reticulata, $P$. ruscifolia and $P$. viridi-glaucescens. Fusoid cells were observed in representatives of some 20 other genera of bamboos that were examined, and they were especially large in Atractocarpa olyraefolia and Puelia ciliata. It should be noted that fusoid cells have also been seen at Kew in species of Neurolepis, Olyra, Pariana, Pharus, Streptochaeta and Streptogyne, a fact which suggests that there may be affinities between these genera and the bamboos. Somewhat similar cells, which are, however, more nearly sausage-shaped, occur in Leptaspis.

(ii) Vascular structure of the midrib.

Transverse sections through the lamina of grasses, taken at a standard level about half way between the apex of the lamina and its base, often show a keel or midrib in a median position. The midrib varies from being scarcely perceptible to very conspicuous in different species, and within each species the appearance of the midrib varies according to the exact level at which the section is taken. The number of vascular bundles in the midrib varies from 1 to 24 or more, the number of bundles being proportional to the area of the transverse section of the midrib. In most grasses with large midribs the vascular bundles are arranged in an arc not far from the abaxial surface, and the bundles themselves are often very unequal in size, or of several distinct sizes. When the midrib is small it generally contains a single median vascular bundle. When one turns to certain taxonomic groups of grasses, however, the simple arc of bundles is found to be replaced by a more complex vascular system. This applies, for example, in certain of the Oryzeae, such as Zizania latifolia Turcz., where, in addition to an abaxial arc of bundles, there is a row of about 5 bundles just below the flat adaxial surface of the midrib, and a few others in a median vertical plane. In this species there are also large intercellular spaces in the ground tissue, which are no doubt a specialization related to its aquatic environment.

The midrib of Zizania is interesting because it is in some ways intermediate between the midrib structure exhibited by most grasses on the one hand and the more complex types characteristic of a large majority of the bamboos. It may be noted in passing, however, that Merostachys riedeliana differs from the other bamboos that I have examined in having no well defined midrib, but this would appear to be exceptional amongst the bamboos as a whole. The appearance of transverse sections of a selection of bamboo midribs cut midway between the apices and bases of the lamina is shown in Fig. II, 3-11. In Fig. II 1A-1C and 2A-2B transverse sections taken at successively lower levels through single midribs of Dendrocalamus brandisii and Shibataea Kumasasa respectively are shown. It is clear from these diagrams that although the vascular system of the midrib is more complex towards the base than towards the apex of leaf, the fact remains that the midribs of most of the bamboos that I have examined have more complex systems of bundles than is characteristic of other grasses, and the bundles are supported by comparatively 


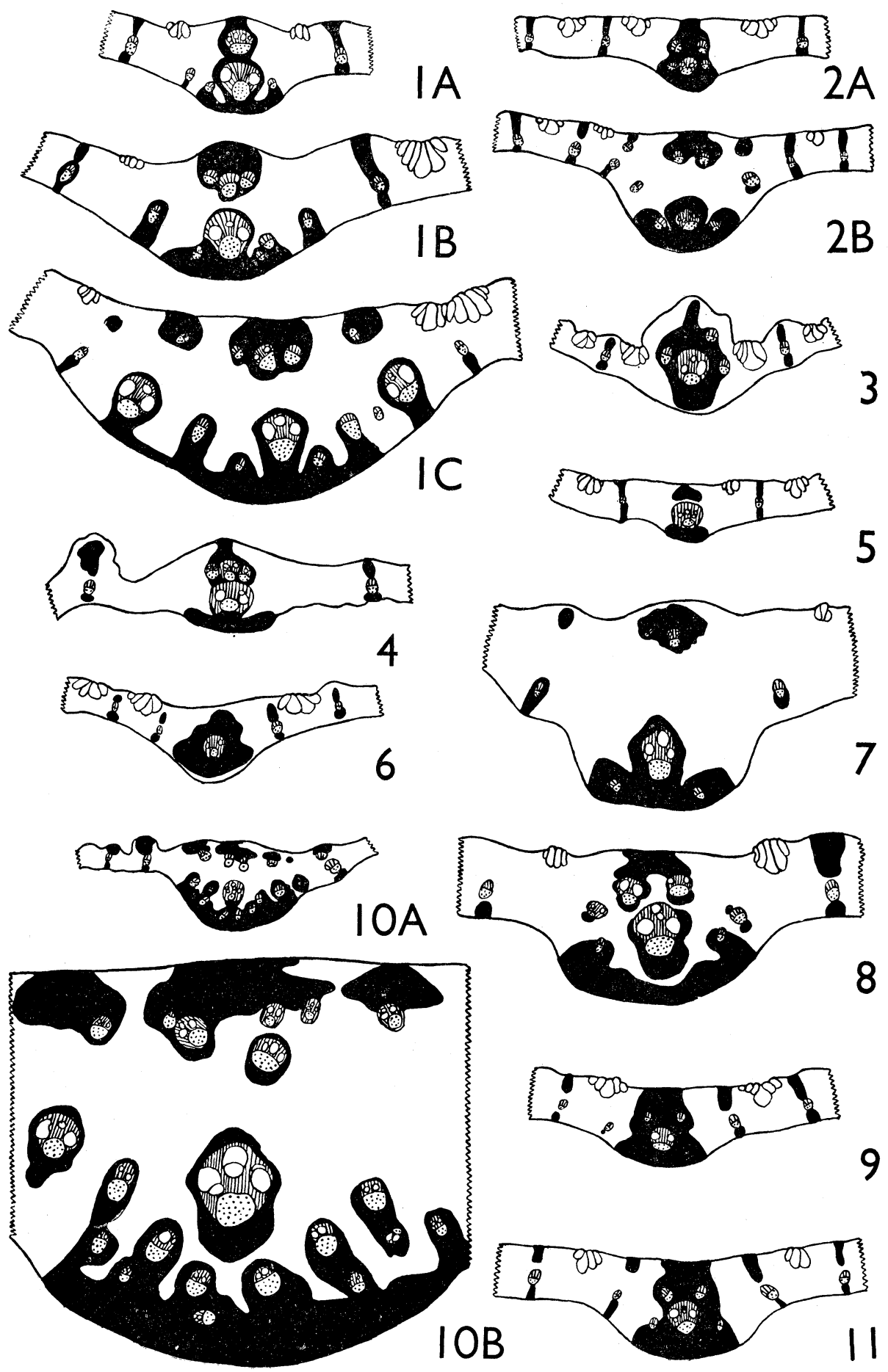


elaborate systems of sclerenchyma. It should be noted, however, that in certain bamboos e g. Arundinaria murielae (Fig. II,5) and Chusquea abietifolia (Fig. II,6) the vascular system is comparatively simple, but the bundles are well supported by sclerenchyma. In most of the species, however, it can be seen that the midrib bundles consist essentially of an adaxial and an abaxial series, all of the bundles being embedded in, or associated with, sclerenchyma. The number of bundles in the adaxial and the abaxial series respectively varies from one species to another. Furthermore the adaxial and abaxial series are, in some species, embedded in, and united by, one more or less continuous mass of sclerenchyma. In other species the adaxial and abaxial series of bundles are separated from one another by thin-walled ground tissue. Differences of this kind can be used to some extent for specific diagnostic purposes.

It is interesting to note that a few grasses not regarded as members of the Bambuseae, exhibit a type of vascular structure in the midrib that recalls that of the bamboos. This applies for example to Neurolepis nobilis Pilger and Streptogyne gerontogaea Hook. f., whilst similar but less complex types of structure have been noted in Olyra latifolius L., Pariana bicolor Tutin, P. campestris Aubl., P. vulgaris Tutin and Pharus latifolius L.

(iii) Bundle sheath.

It is not possible here to enter into a full discussion of the types of bundle sheaths that occur in the bamboos. It must suffice to say that, like previous investigators, I have found the sheaths always to be double, the cells of the outer sheaths being thinner-walled and more parenchymatous than those of the inner sheaths. This fact is of interest because the double type of bundle sheath is usually regarded as a festucoid character.

\section{Abaxial epidermis}

(i) Short cells and silica bodies.

As with other grasses, it is necessary when studying the epidermis of bamboos,

Fig. II. 1A-1C. Dendrocalamus brandisii. T.S. midrib at $\mathbf{3}$ successively lower levels to show the range of structure in an individual leaf. $\times 60$.

2A-2B. Shibataea Kumasasa. T.S. midrib at 2 successively lower levels to show the range of structure in a single leaf. At a higher level in the leaf than that illustrated in $2 \mathrm{~A}$ the midrib is marked by only a single vascular bundle.

3-11. T.S. midribs of bamboos cut in the position that was adopted as a standard for comparative purposes, i.e. about half way between the apex and base of the lamina. All except $10 \mathrm{a} \times 60$.

3. Arthrostylidium capillifolium. 4. Chusquea tenella.

5. Arundinaria murielae.

6. Chusquea abietifolia.

7. Atractocarpa olyraefolia.

8. Oxytenanthera abyssinica.

9. Phyllostachys bambusoides.

10. Gigantochloa ligulata. $\quad 10 \mathrm{~A} \times 12.10 \mathrm{~B}$ A similar, but not identical, section $\times 60$.

11. Phyllostachys viridi-glaucescens.

Solid black, sclerenchyma. Dotted areas, phloem. Vertical lines, xylem. The clusters of large cells in the adaxial epidermis are bulliform cells. 
to distinguish the costal zones above the veins from the intercostal zones between them. In the intercostal zones themselves there are longitudinal strips with and without stomata respectively, and the epidermis, both above and between the veins, is made up of "long" and "short" cells respectively, and dermal appendages of the various types that occur in grasses are also present. The short cells of bamboo leaves, like those of other grasses, can be divided into those which contain silica bodies and those which do not. Short cells between the veins are nearly always in pairs, but occasionally solitary, whilst those over the veins may be in pairs, short rows along the veins, or in much longer but similar rows. Of the 45 species of bamboos belonging to 24 genera that I have examined it has been found that some species are characterized by having the short cells that lie over the veins in pairs, whilst in the other species they are in rows, and, in a third group of species there is a mixture of both types of distribution. Silica bodies above the veins are predominently saddle-shaped, and indeed very few of the bamboos that I have examined are entirely devoid of saddle-shaped silica bodies. In some bamboos the saddleshaped bodies are tall in a direction that lies transversely to the long axis of the leaf. Bodies of this kind could be classified as being of the Oryza type. In some species, bodies that are cross-shaped, dumb-bell shaped, or intermediate between those 2 types occur over the veins, where, they are sometimes intermixed with silica bodies of the dominant saddle-shaped type. In a few species the silica bodies are exclusively cross-shaped and dumb-bell shaped.

Turning now to the short cells between the veins, it may first be noted that there are some species from which intercostal short cells are absent. Where intercostal short cells containing silica bodies are present, however, it is usual to find that, like those over the veins the silica bodies are mostly saddle-shaped, but in some bamboos they are tall and narrow, and may be oval, rounded, or crenate in outline.

(ii) Micro-hairs.

Apart from the short cells and the silica bodies, it can also be seen from epidermal preparations that micro-hairs, i.e. small hairs that are generally 2 -celled, are almost invariably present on bamboo leaves, although they are sometimes difficult to find. Of the 45 species that I have examined there were only 2, Atractocarpa olyraefolia and Puelia ciliata, in which micro-hairs were not detected in the available material on the abaxial surface of the leaf. The hairs most frequently occur in the intercostal zones in longitudinal strips from which stomata are absent. In a few species they occur almost amongst the stomata. Although the sizes, shapes and frequencies of the micro-hairs vary from species to species, they are mainly of one basic type in which both cells are of more or less equal length, the distal cell being of approximately uniform diameter throughout its length, or sometimes tapering slightly towards the apex. In some species, however, particularly in Arundinaria, the basal cell is appreciably longer than the distal cell. Guaduella oblonga is distinguishable 
from the other bamboos that I have examined in having micro-hairs of which each consists of a long basal cell and a distal part which in uniseriate or partly biseriate. The occurrence of micro-hairs in bamboos is of interest because, amongst other grasses their presence is regarded as a panicoid character. They appear to be of restricted diagnostic value amongst the bamboos themselves.

(iii) Long cells and papillae.

The long cells throughout the bamboos are remarkably uniform in type, most of them having sinuous walls. Those of the intercostal zones generally have rather thinner walls, and usually wider, lumina, than those over the veins. The outer walls of the long cells are usually abundantly papillose, the papillae being variable in shape and in the extent to which they are cutinized. There are some bamboos in which papillae are infrequent. Often, besides the outwardly directed papillae, there are others that are bent over the stomata and serve for their protection. The number of papillae overarching the stomata in this way varies from species to species, and from some species they appear to be absent. Sometimes papillae occur around the stomata although they are absent elsewhere on the long cells; in other species, although papillae are present, few of them overarch the stomata. Papillae are specially abundant on long cells in the intercostal zones, but they sometimes occur over the veins as well. Differences in the frequency and distribution of papillae on the long cells appear to be of specific diagnostic value, but are of little diagnostic value at the genus level.

\section{Taxonomic conclusions}

The anatomical observations recorded in this article represent only a small proportion of those which I have made on the structure of bamboos during the past few years. They do, however, point to certain conclusions. Firstly it may be noted that, in the bamboos, we find a combination of anatomical characters that is unusual for the grasses as a whole, and some characters that are peculiar to the bamboos and only a few genera that are not generally regarded as bamboos in existing systems of classification. For example the bamboos exhibit not-radiate assimilatory tissue and double sheaths, two characteristics of festucoid grasses. On the other hand the occurrence of micro-hairs, of cross and saddle-shaped silica bodies, and of short cells in longitudinal rows above the veins, are panicoid characters. There is also a tendency for the saddle-shaped silica bodies to be of the Oryza type in certain species. The fact that the assimilatory tissue usually consists of arm-cells is another character that the bamboos share with the Oryzeae. Taken together, these facts show that certain of the characters that occur in combination in the bamboos have become separated in other groups of grasses, which suggests that the bamboos may be more primitive than other grasses. It should be noted, however, that the bamboos clearly stand out amongst the grasses as a distinct group, apart from a few isolated genera, in having the highly characteristic fusoid 
cells in their mesophyll, and in the complex vascular structure and massive development of sclerenchyma in their midribs.

Another important point is that, although the bamboos exhibit combinations of characters that appear to be diagnostic for the species in which they are exemplified, there are no clear anatomical lines of demarcation between the genera. Indeed to the anatomist the bamboos appear to consist of numerous species that could be interpreted as belonging to only one, or at most only a few, genera. Further work on the structure of the vegetative organs, and of the flowers and fruits, will be necessary before the taxonomy of the bamboos can be more fully understood.

\section{Species examined}

Arthrostylidium capillifolium Griseb., A. pubescens Rupr., Atractocarpa olyraefolia Franch., Arundinaria auricoma Mitford, A. fastuosa Mak., A. fortuni A. \& C. Riv., A. graminea Mak., A. japonica Sieb. \& Zucc. (Sasa japonica Mak.), A. marmorea Mak., A. murielae Gamble, A. nitida Mitford, A. pumila Mitford, A. simonii A. \& C. Riv., A. tessellata Munro, A. vagans Gamble, Bambusa nana Roxb., B. vulgaris Schrad., Cephalostachyum capitatum Munro, Chusquea abietifolia Griseb., C. tenella Nees, Dendrocalamus brandisii Kurz, D. giganteus Munro, Dinochloa m'clellandii Kurz,. Gigantochloa ligulata Gamble, Greslania rivularis Bal.. Guadua paniculata Munro, Guaduella oblonga Hutch., Melocanna bambusoides Trin., Merostachys riedeliana Rupr., Nastus capitatus Munro, N. elegantissimus (Hassk.) Holttum (Chloothamnus elegantissimus (Hassk.) Henr. and Schizostachyum chilianthum Kurz), Ochlandra setigera Gamble, Oreobambus buchwaldii K. Schum., Oxytenanthera abyssinica (A. Rich.) Munro, Phyllostachys bambusoides Sieb. \& Zucc., P. castillonis Mitford, $P$. heterocycla Matsum., P. nigra Munro, $P$. reticulata C. Koch, P. viridiglaucescens A. \& C. Riv., Pseudostachyum polymorphum Munro, Puelia ciliata Franch., Shibataea Kumasasa Mak., Thyrsostachys oliveri Gamble.

\section{Ref erences}

1. Brandis, D., Trans. Linn. Soc. London. Bot. Ser 2, 7:69-92 (1907). 2. Jacques-Félix, H., Journ. Agric. Trop. et Bot. appliquée 2: 423-30 (1955). 3. Ohki, K., Bot. Mag. Tokyo 41-44 (1927-30). 4. Ohki, K., Journ. Fac. Sci. Tokyo Univ. 4:1-130 (1932). 5. Page, V. M., Bull. Torrey Bot. Cl. $74:$ 232-9 (1947). 6. Prat, H., Ann. Sci. Nat. b. ser. 10: 18: 165-258 (1936). 